\title{
Sedimentary dynamics on isolated highs in Lake Baikal: evidence from detailed high-resolution geophysical data and sediment cores
}

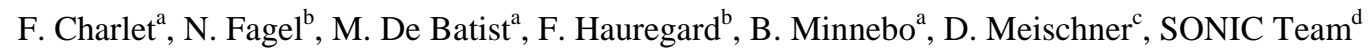 \\ ${ }^{a}$ Renard Centre of Marine Geology, Ghent University, Ghent, Belgium \\ ${ }^{b}$ U.R. Argiles and Paléoclimats, University of Liège, Liège, Belgium \\ ${ }^{c}$ Hydromare, Am Weendelsgraben 6, D-37077 Göttingen, Germany \\ ${ }^{d}$ SONIC, St. Petersburg, Russia
}

\begin{abstract}
High- and very-high-resolution seismic data, side-scan sonar mosaics and piston cores from three isolated highs in Lake Baikal (Vydrino Shoulder, Posolsky Bank, Continent Ridge) have allowed to document in unprecedented detail the depositional, re-depositional and tectonic processes and to characterise the overal sedimentary environment on such isolated highs. Our data show that Vydrino Shoulder actually represents a turbidity- or underflow-sourced slope fan, with a distinct channel-levee morphology, and affected by tectonics and stratigraphic unconformities. Sediment cores contain up to $90 \%$ of terrigenous material. Posolsky Bank is a major tilted fault block, clearly affected by tectonic activity, by stratigraphic unconformities and by mass wasting along its margins. Sedimentation on its crest is undisturbed, but average sedimentation rates are high due to the influence of the nearby Selenga River. Continent Ridge is also affected by active faulting, stratigraphie unconformities and by mass-wasting along its flanks. The area receives only $30 \%$ of terrigenous input. There are no signs of sediment reworking due to bottom-currents. Our study thus shows that in comparison with other environments in Lake Baikal, the isolated highs probably hold the best potential to contain a high-quality, continuous, undisturbed and undiluted sedimentary record suitable for paleoclimate research.
\end{abstract}

Keywords: Lake Baikal; Sedimentation; Reflection seismics; Side-scan sonar

\section{Introduction}

Lakes are excellent sensors of environmental and climatic change, and sedimentary lake records are exceptionally well suited for high-resolution, multi-proxy paleoclimate studies (e.g. Battarbee, 2000). On the scale of their catchment, lakes record regional responses to changes in the global climate system, and a combination of such records from multiple sites can contribute to a better understanding of climate processes and of interactions between different climate systems and between different regions, and their variations over time. The lacustrine records most suitable for paleoclimate research are those that result from the gradual and steady accumulation of ideally mostly biogenic sediments, preferably in small lakes with minimal riverine, glacial or tectonic influences. Such records, however, are usually quite limited in time (typically up to a few tens of thousands of years). Records covering longer time spans (up to hundreds of thousands or millions of years) are usually only contained in large lakes, which are mostly of tectonic origin. The larger the lake, however, the higher is the risk of influences that may complicate, obscure or destroy the paleoclimate record such as currents, turbidites, mass-wasting, and tectonics. In such settings, utmost attention should therefore be paid to clearly understand the depositional environment prior to the selection of coring or drilling locations.

Lake Baikal in Siberia is among the best examples of such a large, tectonic lake with a very long sedimentary record. It is the largest (23,000 $\left.\mathrm{km}^{3}\right)$ and deepest (1642 m) lake on Earth (Galazy, 1993; INTAS Project 99-1669 Team, 2002), and its sedimentary infill of nearly $10 \mathrm{~km}$ thick represents a history of probably more than 25 million years (Zorin, 1971; Nikolayev et al., 1985; Hutchinson et al., 1992; Mats et al., 2000). The lake occupies the central part of the presently still active Baikal Rift Zone. Morphologically, it can be sub-divided into three deep basins (the South, Central and North Baikal Basins), which are separated by inter-basin highs (the Selenga Delta accommodation zone, or Buguldeika Saddle, and the Academician Ridge accommodation zone).

Sediments retrieved from various locations within Lake Baikal have been studied extensively since the early 1990s in the framework of the international Baikal Drilling Project (BDP), but also by several other paleoclimate investigations (a.o. Colman et al., 1995; Grachev et al., 1998; Kashiwaya et al., 2003; Kuzmin et al., 2000; Williams et al., 1997; 2001).

Unfortunately, not all locations and depositional environments from which these sediment cores were collected proved suitable for paleoclimate analyses: 
- Sediments from the North Basin, the one most intensively affected by the Quaternary glaciations, show a clear overprint of the glacial processes and associated high fluxes of glacigenic clastics (Back et al., 1998; 1999).

- The deep basin floors of the South and Central Basins are generally dominated by turbidite systems (Nelson et al., 1995, 1999; Colman et al., 2003). These turbidites, which occur frequently in this tectonically and seismically highly active rift basin, tend to dilute the lacustrine background sedimentation and to disrupt the continuity of the sedimentary record.

- Major river deltas (Upper Angara, Barguzin or Selenga River deltas) are characterised by very high sedimentation rates and have a strong overprint of riverine processes, for the terrigenous as well as for the biogenic fraction.

- The crests of the inter-basin highs separating the Baikal sub-basins (e.g. Academician Ridge, Buguldeika Saddle) have long been regarded as the ideal environment for paleoclimate studies, as they are protected from turbidite activity and accumulate only hemipelagic sediments. Recent studies, however, have shown that the sedimentary record on these ridges may locally be affected by tectonic disruptions (Mats et al., 2000) and by the action of bottom-water currents (Ceramicola et al., 2001) and may thus be less continuous and uninterrupted than previously thought.

For this study, carried out in the framework of the EC-funded CONTINENT project, we therefore targeted another type of environment: the isolated highs. These highs are high enough above the basin floors to be free of turbidites (to insure a good, continuous, undisturbed and undiluted climate record), far enough from river inflows, isolated and small enough to be unaffected by bottom-water currents. In this paper, we will present a complete suite of geophysical site-survey data and core descriptions from three such isolated highs in Lake Baikal, use these data to characterise the prevailing sedimentation processes on these highs and evaluate the potential of these environments for yielding a paleoclimatically valuable sediment record.

\section{Study areas}

Three isolated highs were selected for this study: Posolsky Bank, Vydrino Shoulder and Continent Ridge (Fig. 1).

Vydrino Shoulder is located at the southeastern margin of the South Baikal Basin, off the Hamar-Daban Mountain Range and opposite the Angara River outflow. It forms an upper- to mid-slope terrace, at 500 to $800 \mathrm{~m}$ water depth, affected by active faults and cut by several canyons.

Posolsky Bank, located in the eastern part of the Southern Baikal Basin, is a tilted fault block within the Selenga Delta Accommodation Zone (Hutchinson et al., 1992; Zonenshain et al., 1992; Scholz et al., 1993; Scholz and Hutchinson, 2000). This area is part of the structurally complex boundary system between the South and Central Baikal Basins. Its crest reaches water depths of less than $50 \mathrm{~m}$. The southern slope is very steep and coincides with the Posolsky border fault, i.e. the northern boundary fault of the South Baikal Basin, whilst the northern slope is more gradual.

Continent Ridge is a more or less isolated structural high North of the Svyatoi Nos Peninsula, along the eastern coast of the North Baikal Basin. It is structurally connected to Academician Ridge, but morphologically isolated from it. Its crest reaches a water depth of less than $100 \mathrm{~m}$.

\section{Material and methods}

The CONTINENT geophysical site-survey data and sediment cores were collected in July 2001 from R/V Vereshchagin (Limnological Institute, Irkutsk, Russia).

\subsection{Geophysical data}

Two different types of reflection seismic data were collected in each of the study areas: a first grid of highresolution sparker profiles and a second, denser grid of very-high-resolution pinger profiles. The high-resolution profiles were shot using RCMG's multi-electrode sparker (energy: $500 \mathrm{~J}$ ) as seismic source and a SIG singlechannel streamer as receiver. The signal was bandpass-filtered between 400 and $2000 \mathrm{~Hz}$ in order to eliminate electric and ship's noise. The very-high-resolution profiles were acquired with a GeoAcoustics $3.5 \mathrm{kHz}$ subbottom profiler and bandpass-filtered over a narrow frequency band centred around $3500 \mathrm{~Hz}$. Navigation and 
positioning was done by GPS. Both types of seismic data were recorded digitally with an ELICS-Delph2 system. In total, $240 \mathrm{~km}$ of sparker profiles (Continent Ridge: 49 km; Posolsky Bank: $101 \mathrm{~km}$; Vydrino Shoulder: 90 km) and $87 \mathrm{~km}$ of pinger profiles (Continent Ridge: $37 \mathrm{~km}$; Posolsky Bank: $29 \mathrm{~km}$; Vydrino Shoulder: $21 \mathrm{~km}$ ) were acquired.

Post-acquisition data processing was carried out either on a Landmark ProMax system or on a SMT Kingdom Suite system. Applied processing routines included frequency filtering, spiking deconvolution and scaling, with main purpose to increase resolution and image quality. The processed sparker data show on average 200-300 ms TWT penetration and a theoretical resolution of $50-75 \mathrm{~cm}$; the pinger profiles have a lower penetration (up to 50$60 \mathrm{~ms}$ TWT) and a higher resolution $(25-30 \mathrm{~cm})$.

Side-scan sonar data were recorded with the $30 \mathrm{kHz}$ SONIC-3 system. It was towed at 100-200 m above the lake floor and imaged about $0.8 \mathrm{~km}$ at each side of the track line. The across-track footprint of the acoustic beam ranged from 0.75 to $3.8 \mathrm{~m}$. The data were post-processed using in-house developed software in order to reduce noise, increase data quality and clarity, to georeference and correct the records and to produce a positive-polarity (i.e. light color corresponds to high backscatter) mosaic image of the surveyed sites. The SONIC-3 system also carries a $5 \mathrm{kHz}$ subbottom profiler, which recorded additional very-high-resolution seismic profiles along the surveyed tracks. The penetration of these pinger data is up to $30-40 \mathrm{~m}$, and the vertical resolution about $10 \mathrm{~cm}$. In total, about $260 \mathrm{~km}$ of side-scan sonar and pinger tracks were collected (Continent Ridge: $55 \mathrm{~km}$; Posolsky Bank: 125 km; Vydrino Shoulder: $80 \mathrm{~km}$ ).

For interpretation, the geophysical site-survey data were combined with updated bathymetry information (INTAS Project 99-1669 Team, 2002), which turned out especially useful for the interpretation of morphologies and lake-floor sediment texture from the side-scan sonar mosaics.

Fig. 1: Location map of the three study areas in Lake Baikal. Indication of seismic track lines (and of the profiles shown in this article), of the area covered by side-scan sonar mosaic, of the location of the CONTINENT piston cores and of bathymetry (INTAS 99-1669 project, 2002).

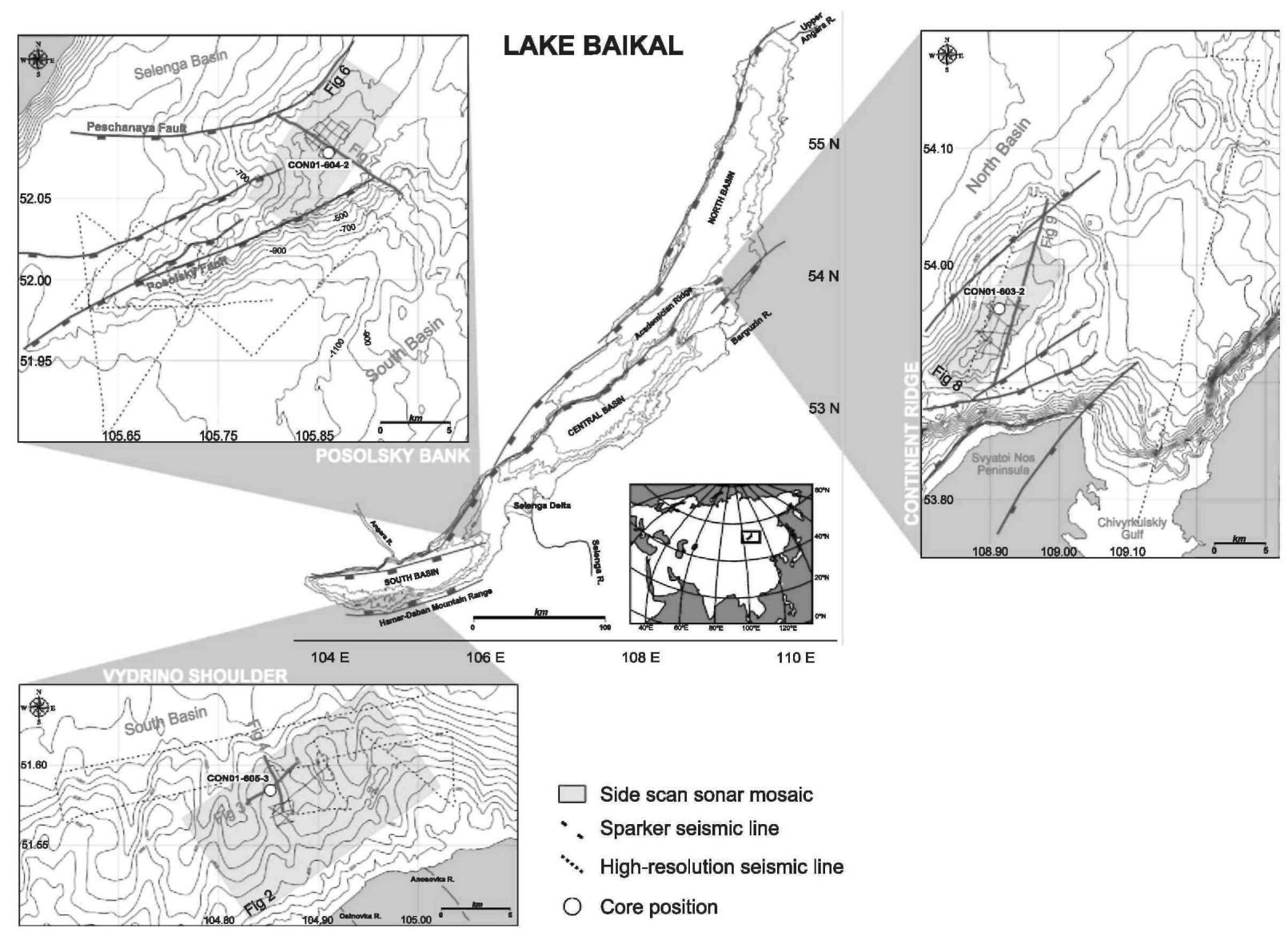




\subsection{Sediment cores}

Several piston cores were taken in each of the study areas, using 120/110 mm diameter aluminium core barrels without liners on a Göttigen-type piston corer (Kögler, 1963; Meischner and Rumohr, 1974). Three of these cores were selected for this study (Fig. 1): CON01-603-2 (Continent Ridge; $53.9633^{\circ} \mathrm{N} 108.9130^{\circ} \mathrm{E} ; 1127.5 \mathrm{~cm}$ long); CON01-604-2 (Pos-olsky Bank; 52.0795 ${ }^{\circ} \mathrm{N} 105.8575^{\circ} \mathrm{E} ; 624.5 \mathrm{~cm}$ long) and CON01-605-3 (Vydrino Shoulder; $51.5849^{\circ} \mathrm{N} 104.8548^{\circ} \mathrm{E} ; 1051.5 \mathrm{~cm}$ long).

After opening and splitting of the cores, the sedimentological characteristcs were described and sediment colors were estimated using the Geological Society of America Rock Color Chart (Goddard et al., 1948). The core was then sub-sampled each $10 \mathrm{~cm}$ for smear slides, which provided a semi-quantitative estimation of the biogenic and detrital components. X-ray radiographs were made of the entire core on 1-cm-thick slices of sediment, and this yielded information on the characteristics of sedimentary and tectonic features (e.g. the type of lamination, slumps, faults or burrows). All lithological and sedimentological information was then combined into a lithological log for each of the cores.

\section{Vydrino Shoulder}

\subsection{Side-scan sonar mosaics}

In combination with the new bathymetric data, the side-scan sonar mosaic reveals the morphology of the Vydrino Shoulder area as highly complex (Fig. 2), much more than expected from the previously available bathymetric data (USSR Ministry of Defence, 1992). The morphology is one of a series of elevated ridges, more or less perpendicular to the coast, separated by deeply incised canyons or channels. The relief is most contrasted and complicated in the mid-slope section, with a maximum bathymetric difference of around $300 \mathrm{~m}$, from the summit of the ridges to the deepest channels. The morphology gets more subdued towards the deep basin floor and towards the shore (i.e. the canyons do not extend to the shoreline).

The ridges are characterised by a homogeneous low-backscatter sonar facies, suggesting a predominance of medium- to fine-grained sediments. This is in agreement with the relatively high penetration of the $5 \mathrm{kHz}$ pinger profiles on the ridges (up to 20-30 m) and is confirmed by a series of short sediment cores (Sturm and Baster, personal communication). Piston core CON01-605-3 was collected on the crest of such a ridge. The crests of the ridges are quite flat. The flanks are incised by small gullies, with slopes of $10^{\circ}$ to $12^{\circ}$, and sediment destabilisations indicating mass-transport from the ridges into the channels.

The channels are mostly flat-floored and show very strong, high-amplitude sonar returns, suggesting that the channel fill is mainly composed of coarse, sandy material. Pinger profiles across the channels show very highamplitude reflections and almost no penetration. Sporadic sediment waves in the channels are illustrative of the coarser nature of the sediment and of the high-energy conditions (most likely involving turbidite or hyperpicnal flows). The sediment waves also indicate the direction of net sediment transport.

\subsection{Pinger and sparker seismic data}

The high-resolution pinger profiles confirm the strong contrast between the ridge crests with relatively good acoustic penetration, and the channels with virtually no penetration (Fig. 3). The flanks of the ridges, characterised by steep and often fault-controlled slopes, present many slumps and sediment destabilization features.

Sparker profile Cont47 shows that the upper 250-300 ms TWT (about 200-240 m) of the sedimentary section on the coring site (i.e. on a ridge crest) can be sub-divided into three main unconformity-bound seismicstratigraphic units: Units 1, 2 and 3 from top to base (Fig. 4).

They are each about $100 \mathrm{~ms}$ TWT ( $80 \mathrm{~m})$ in thickness and characterised by different combinations of seismic facies:

- Unit 1 is characterised by a more or less homogeneous high-amplitude and stratified seismic facies. The facies suggests a rather stable depositional environment. The CON01-605-3 piston core did not penetrate the base of this unit (Fig. 4).

- Units 2 and 3 show an alternation of low- and high-amplitude facies, chaotic and stratified, respectively. These 
different facies could be interpreted as disorganised mass-wasting deposits (chaotic facies) and relatively coarsegrained stratified deposits, possibly turbidites (stratified facies). The stratified facies shows some resemblance to that of the overlying unit.

Fig. 2: Side-scan sonar mosaic of Vydrino Shoulder and its interpretation. Indicated are bathymetry and location of core CONOl-605-3.
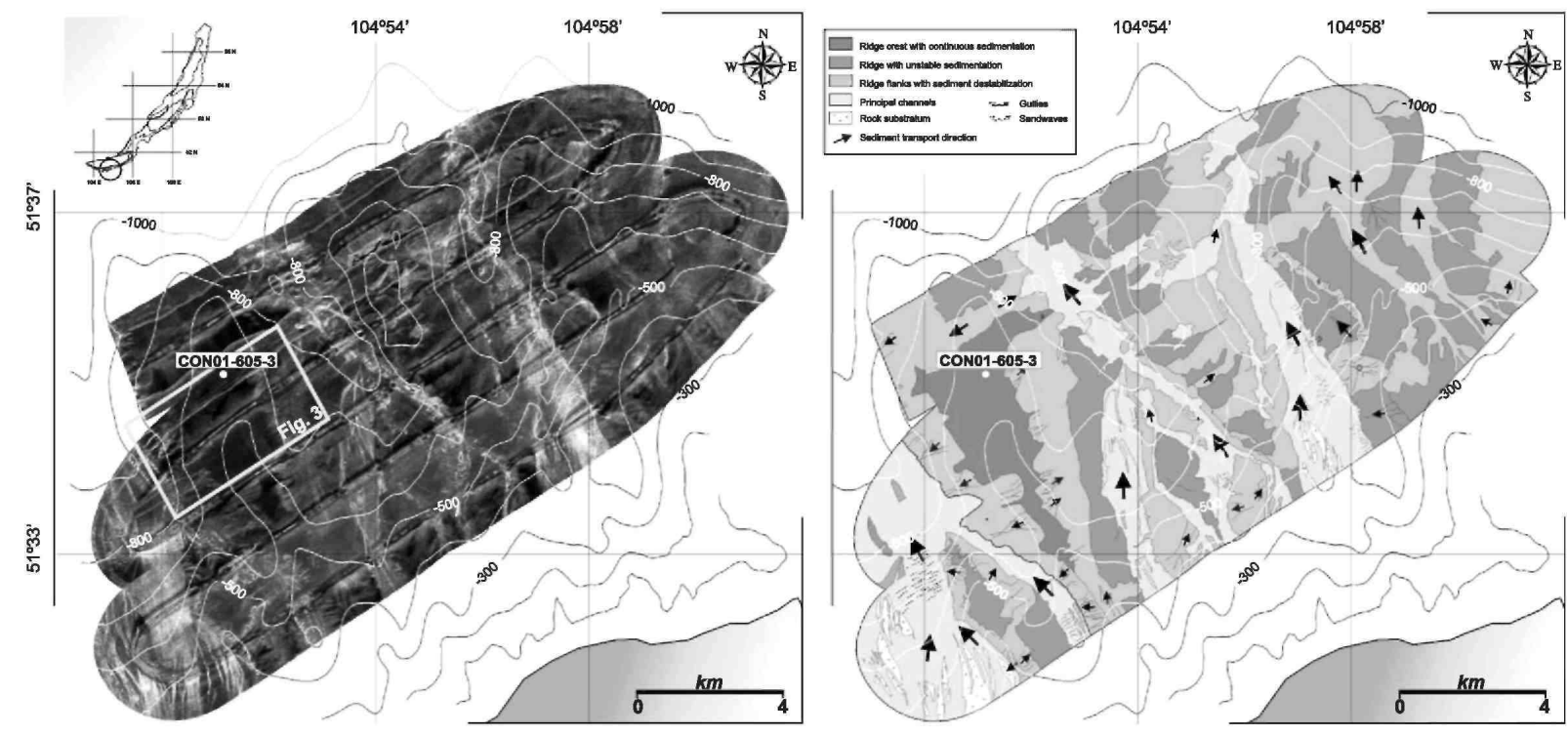

Fig. 3: Side-scan sonar zoom of the ridge at the CONOl-605-3 coring site and related $5 \mathrm{kHz}$ subbottom profiler.

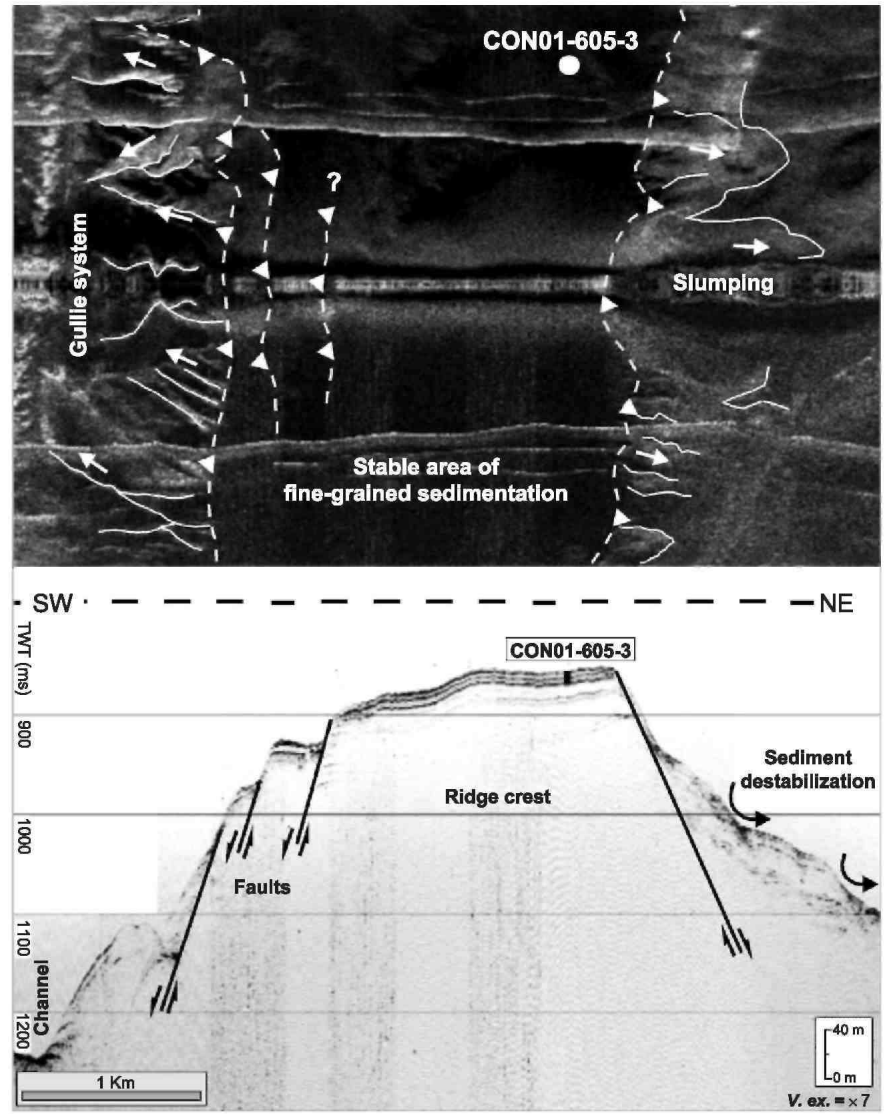


The sparker profiles also show that the area has been affected-to a variable degree-by tectonic activity. The tectonic deformations, consisting of normal faults with regionally or counter-regionally dipping fault planes and variable offsets, affect all units, but they are more pronounced in the lower Units 2 and 3. This indicates a decrease of the tectonic activity through time. Moreover, some faults also seem to affect only the upper units and disappear at depth (Fig. 4). This is probably due to the relative orientation of the seismic profile with respect to the dipping fault plane, causing the upper part of the fault to be imaged by the profile and the lower part not. The tectonic influence is also more outspoken in the northern part of the profile, whilst the southern part is characterised by a much more undisturbed stratification.

Fig. 4: Sparker profile Cont47 across the CON0l-605-3 coring site on one of the ridges of Vydrino Shoulder, and its interpretation. For location see Fig. 1.
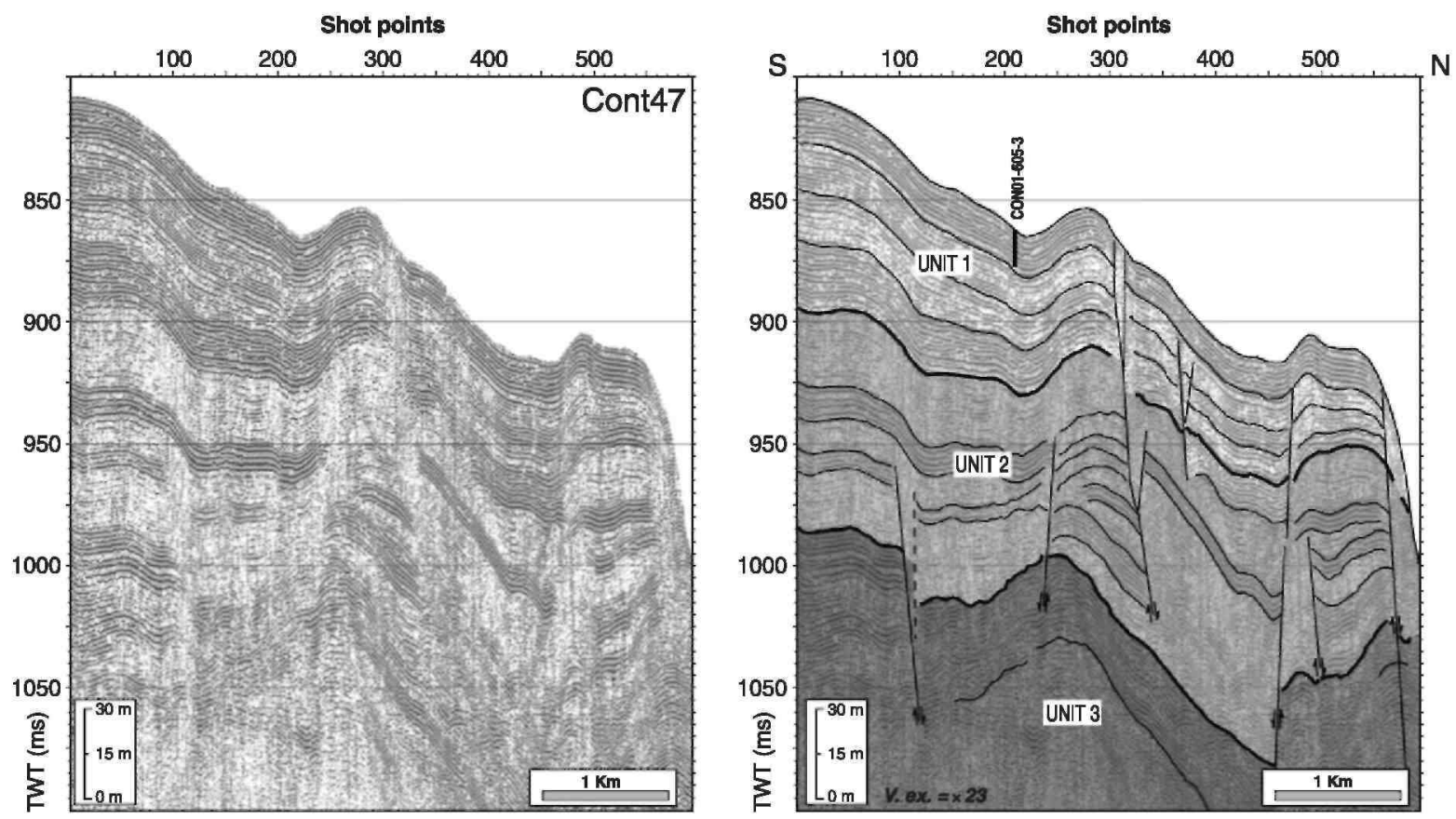

\subsection{Sedimentological data}

The lithology of core CON01-605-3, corresponding to the upper part of seismic Unit 1, is dominated by detrital muds with only 1-m-scale diatom-rich interval in the upper part of the core (Fig. 5). The sediment shows only a few remarkable sedimentary structures, such as lenticular bedding, cross stratification and erosive scouring. The core shows little influence of tectonics: one slump and two small faults are observed. Bioturbation is restricted to a few centimeter-scale burrows. The sedimentary texture, extremely variable, is nebulous to coarsely laminated.

The core can be sub-divided into three main lithological units (Fig. 5):

(1) The upper part of the core $(0-107 \mathrm{~cm})$ displays gray silty clay to clayey silt. Diatoms are common in the upper $10 \mathrm{~cm}$ and decrease gradually between 10 and $75 \mathrm{~cm}$. Below $75 \mathrm{~cm}$, only a few diatoms are observed and the sediment color gradually shifts from gray to dark olive gray. The sediment texture is diffuse with some discontinuous and irregular dark (grayish black to dark gray) laminations, streaks and lenses of metastable iron sulphides (probably mackinawite).

(2) Between 107 and $610.5 \mathrm{~cm}$, the sedimentation is mainly detrital with dark gray silty clay and clayey silt. In addition, eight homogenous dark gray to medium light gray sandy layers occur between 170 and $371 \mathrm{~cm}$. Rare to very few diatoms are observed until $160 \mathrm{~cm}$ depth. The texture is mainly diffuse, but the sediment is finely laminated in two pluridecimetric intervals (135-170 and 569-610.5 cm) and coarsely laminated in two others (170-342 and 499-569 cm). The laminations are usually defined by micaceous silty layers. Numerous sporadic little black concretions of metastable iron sulphide are observed throughout this unit.

(3) Below $610.5 \mathrm{~cm}$, the sediment is clayey, homogeneous without any internal texture (except one fault in the lower part). Some dropstones are scattered through this interval. In our interpretation, this sediment texture 
represents the true, original texture of the deposits at that depth. It can, however, not be excluded that it could also be due to a coring artefact.

Fig. 5: Lithologs of the three piston cores from Vydrino Shoulder (CON01-605-3), Posolsky Bank (CON0l-604-2) and Continent Ridge (CON01-603-2). For reasons of conformity, symbols are similar to other published logs from Lake Baikal (Fagel et al., 2003).




Fig. 6: Side-scan sonar mosaic of Posolsky Bank and its interpretation. Indicated are bathymetry and location of core CON01-604-2.
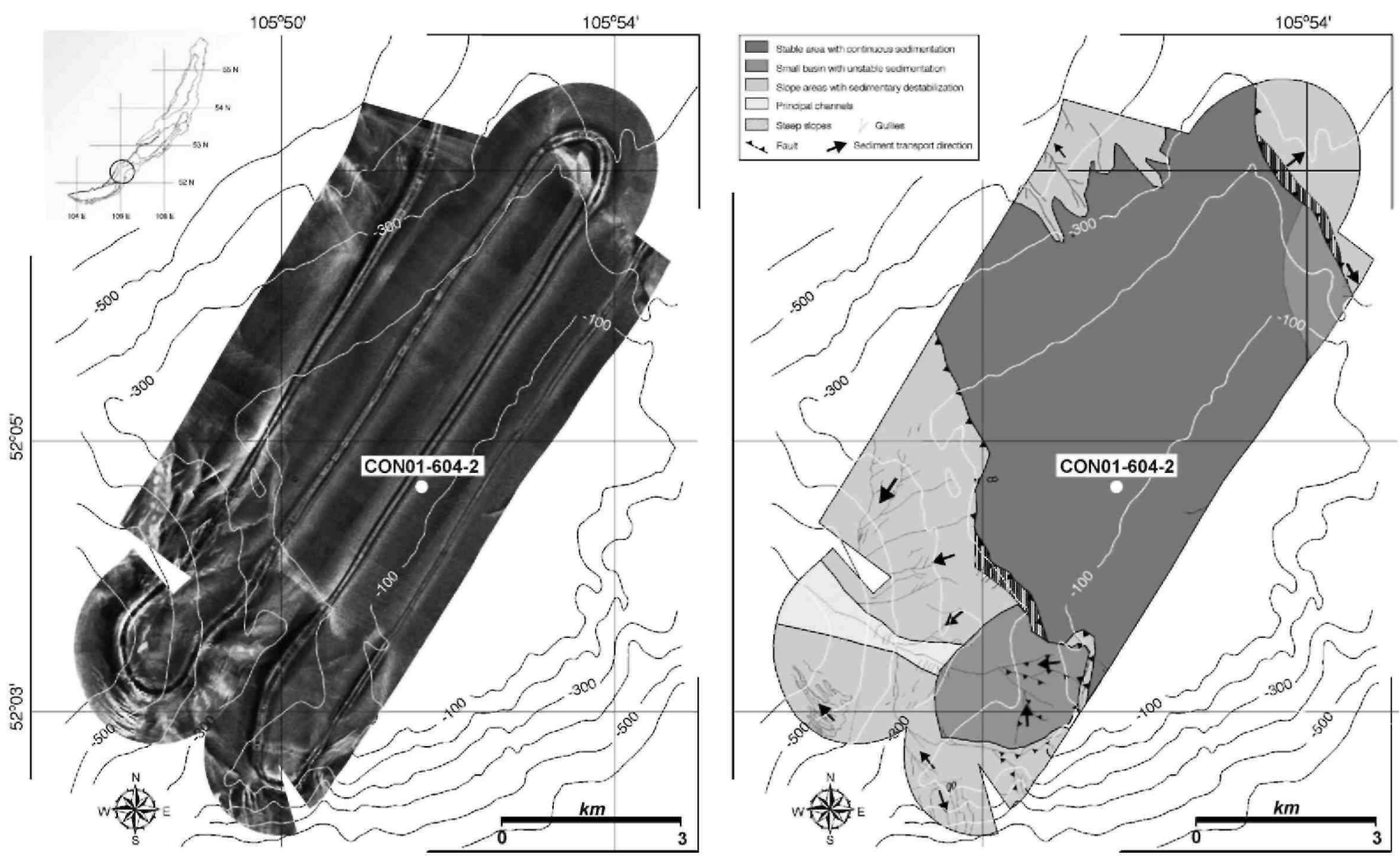

\section{Posolsky Bank}

\subsection{Side-scan sonar mosaics}

The side-scan sonar mosaic from Posolsky Bank (Fig. 6) shows the morphological characteristics of this shallow high. The central part of the Bank (east-central side of the mosaic) is characterised by a flat, smooth morphology interpreted to represent an environment of undisturbed, quiet sedimentation. The average backscatter energy indicates a predominance of relatively fine-grained sediments. This is confirmed by short sediment cores (Sturm and Baster, personal communication).

The margins and slopes of the bank $\left(\sim 7^{\circ}\right.$ and $\sim 20^{\circ}$ steep, on the eastern and western slopes, respectively) show evidence of slumping and faulting (Fig. 6). Especially the southwestern part of the mosaic shows a more irregular morphology and a higher-energy sedimentary environment with a major, possibly fault-controlled, incised channel that appears to direct sediments towards the South Baikal Basin. The high-amplitude response of the sonograms and the $5 \mathrm{kHz}$ pinger profiles suggest that the channel fill is mainly composed of coarse, sandy material.

\subsection{Sparker and pinger seismic data}

According to sparker profile Cont31, the upper 200-300 ms TWT (about 160-240 m) of the sedimentary cover on Posolsky Bank can be subdivided into five main seismic-stratigraphic units (Units 1 to 5 from top to base), separated by distinct angular unconformities (Fig. 7). These sedimentary units have variable thicknesses.

- Unit 1 is only a few meters thick. It covers almost the whole area and drapes the pre-existing morphology (even on the slopes). This unit is only slightly affected by faulting. The CON01-604-2 piston core did not penetrate the base of this unit (Fig. 7).

- Units 2, 3 and 4 all display a more or less regular alternation of low- and medium-amplitude packages, each typically a few meters to $10 \mathrm{~m}$ thick. They indicate that the dominant depositional process has varied regularly 
during the formation of these three units. The thickness of these units varies laterally, and is influenced by faulting at the margins of the bank. The influence of faulting becomes gradually less pronounced in the younger units.

- Unit 5 shows a weak stratification and is mostly characterised by low reflection amplitudes. There is evidence for a few higher-amplitude reflections deeper in this unit.

The channel in the southwestern part of the study area is characterised by common slumps and other masswasting features, chaotic facies, etc. This is probably due to the influence of tectonics, as suggested by the observation of faults on side-scan sonar images and seismic profiles.

\subsection{Sedimentological data}

Core CON01-604-2 from Posolsky Bank, corresponding to almost the entire seismic-stratigraphic Unit 1, comprises three main lithologies, present in similar proportions: biogenic diatom-bearing material, mixed biogenic/detrital material and pure clayey material (Fig. 5). Two diatom-rich intervals can easily be discerned. The core presents different textures (mainly nebulous or finely laminated) and bedding types (parallel bedding, cross stratification, erosive contact). The sediment is only slightly influenced by tectonics since only a few faults and slumps can be observed. Bioturbation is relatively widespread and expressed as isolated, narrow burrows (2$4 \mathrm{~cm}$ long, $3 \mathrm{~mm}$ wide) that affect the biogenic and detrital intervals indifferently.

The core can be sub-divided into six lithological units (Fig. 5):

(1) The upper part of the core $(0-47.5 \mathrm{~cm})$ is finely laminated, and consists of olive-gray to medium dark gray clayey silt to silty clay with common diatoms. The diatom abundance is high in the upper $20 \mathrm{~cm}$ and decreases to a few $(20-40 \mathrm{~cm})$ or very few specimens $(40-47.5 \mathrm{~cm})$.

(2) Between 47.5 and $205 \mathrm{~cm}$, the material is mainly detrital. It comprises olive-gray to dark greenish gray clay and clayey sediment with silt. No or very rare diatoms are observed in this interval.

(3) Between 205 and $236 \mathrm{~cm}$, the core is characterised by dark greenish gray clayey muds with few diatoms.

(4) From $236 \mathrm{~cm}$, the diatom abundance increases gradually and then fluctuates down to $395 \mathrm{~cm}$. The sediment consists of olive-gray to dark greenish gray clays and silty clays. Numerous burrows filled by yellowish brown material are concentrated in this interval. All of the observed faults occur in this interval.

(5) Between 395 and $447.5 \mathrm{~cm}$, the sediment includes a few diatoms. The detrital components are grayish olive to dark olive gray silty clays.

(6) From $447.5 \mathrm{~cm}$ to the base of the core $(624.5 \mathrm{~cm})$, the material is purely clayey, olive gray to dark greenish gray in color. Some burrows are scattered in this lithological unit. 
Fig. 7: Sparker profile Cont31 across the CON01-604-2 coring site on Posolsky Bank, and its interpretation. For location see Fig. 1.
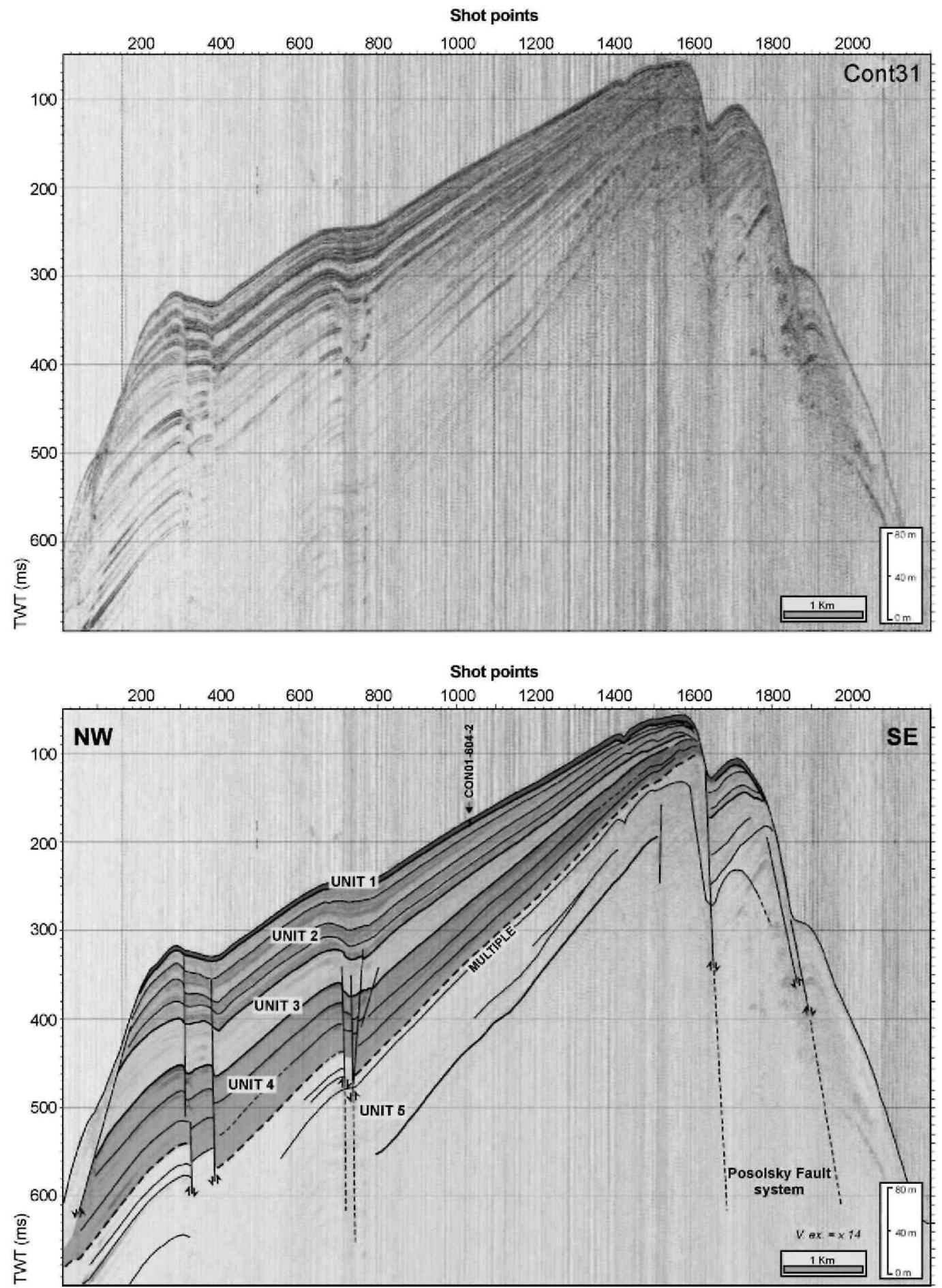
Fig. 8: Side-scan sonar mosaic of Continent Ridge and its interpretation. Indicated are bathymetry and location of core CON01-603-2.
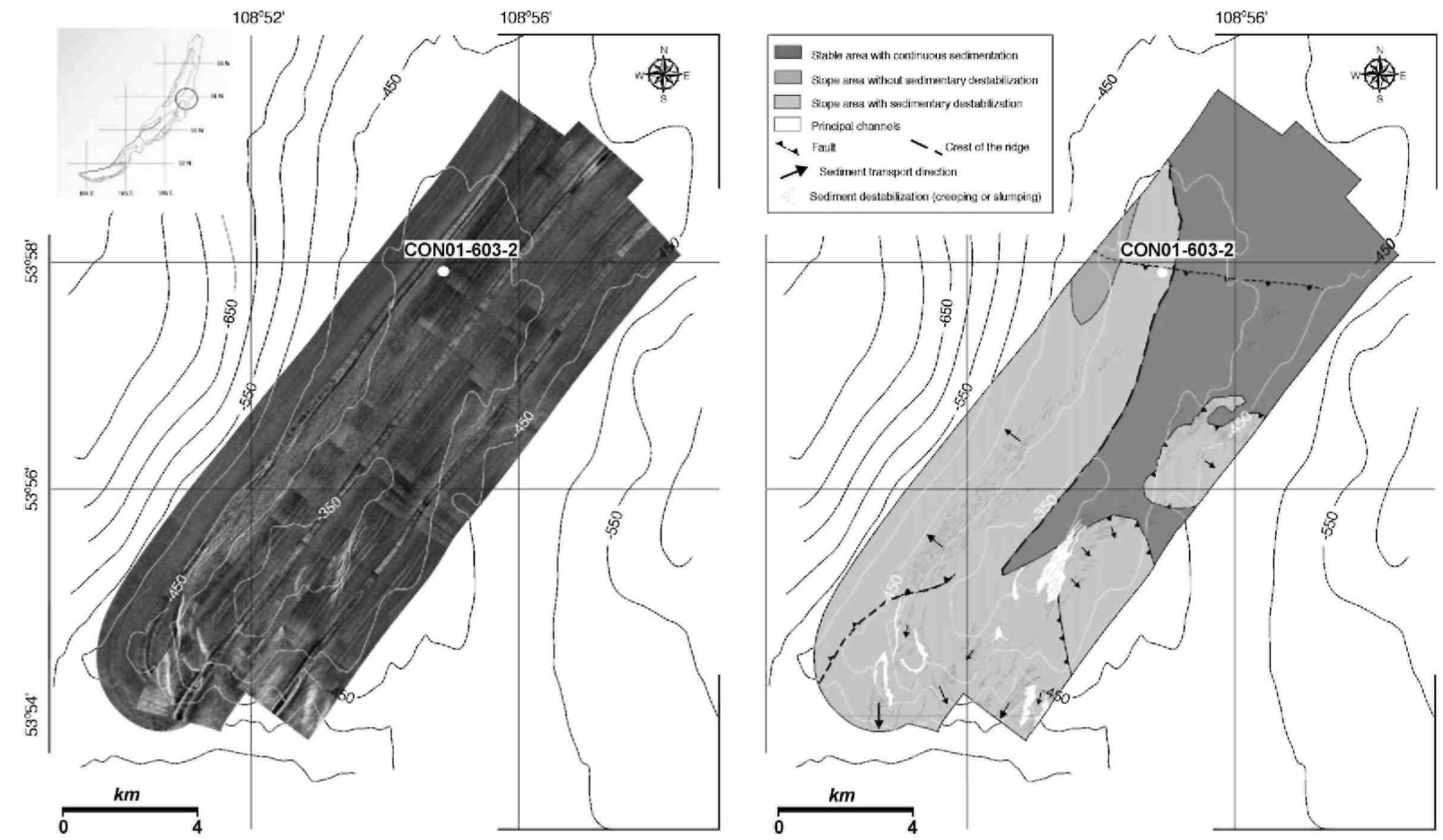

\section{Continent Ridge}

\subsection{Side-scan sonar mosaics}

The side-scan sonar mosaic of Continent Ridge (Fig. 8) illustrates the general morphology of the area. The crest of the ridge is characterised by a relatively flat, smooth morphology interpreted to represent a quiet environment of undisturbed sedimentation. The low average backscatter energy indicates a predominance of homogeneous, fine-grained sediments. The margins and slopes of the ridge display destabilization features, such as slumping and creeping, which have been confirmed by a series of short sediment cores (Sturm and Baster, personal communication). These, however, do not affect the crest of the ridge on its eastern part.

\subsection{Sparker and pinger seismic data}

The sparker profiles show that the upper 200-250 ms TWT (about 160-200 m) of the sedimentary cover at the piston coring site on Continent Ridge can be sub-divided into five main lithological units: Units 1 to 5 from top to base (Fig. 9). These units are typically about $50 \mathrm{~ms}$ TWT thick ( 40 m), except for Unit 1, which is only 20 ms TWT thick $(\sim 16 \mathrm{~m})$.

- Units 1 and 2 are characterised by continuous, high-amplitude reflections. The boundary between these two units is a (correlative) conformity, although locally minor onlaps can be observed in the vicinity of faults. The CON01-603-2 piston core only sampled the upper part of Unit 1 (Fig. 9).

- Units 3, 4 and 5 consist of an alternation of low-and high-amplitude reflections, indicating a distinct variability in time of the dominant depositional processes. The boundaries between these different units are slight angular unconformities, and there are indications of syn-sedimentary tectonic activity or of short interruptions (hiatuses) in the sedimentation.

Like the coring sites on Posolsky Bank and Vydrino Shoulder, the sedimentary units of Continent Ridge are also influenced by tectonics and affected by faulting. The mostly normal faults can have a displacement of up to 50 ms TWT $(\sim 40 \mathrm{~m})$, but most are much smaller and often occur in clusters. Such micro-faulting clusters mainly 
affect Units 1 to 3 (Fig. 9) and appear to be the near-surface expression of a deeper single fault. They significantly influence the continuity of the sedimentary cover. Some of the observed faults also affect the lake floor morphology, as observed on the side-scan sonar mosaic (Fig. 8).

Fig. 9: Sparker profile Cont05 across the CON01-603-2 coring site on Continent Ridge, and its interpretation. For location see Fig. 1.
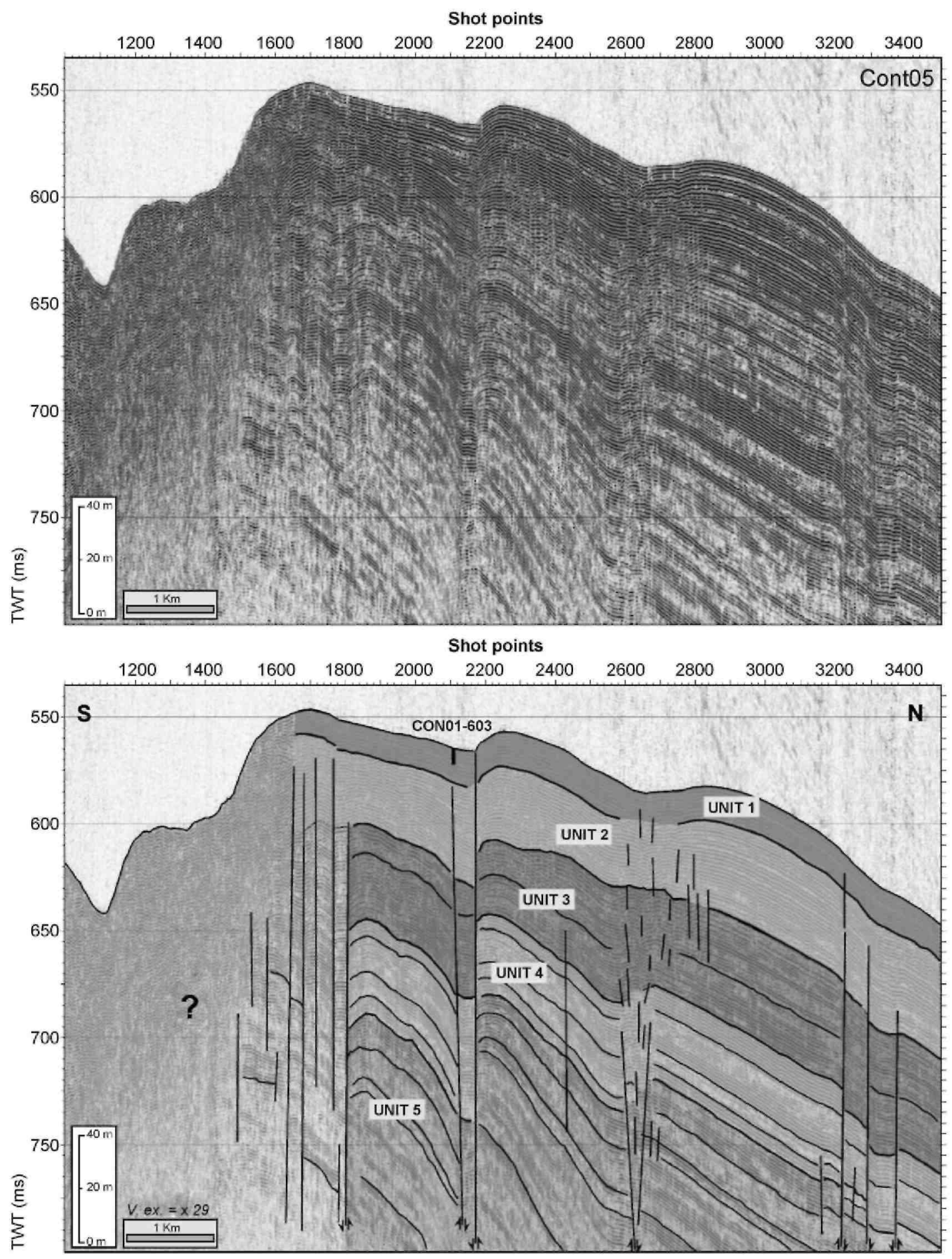

\subsection{Sedimentological data}

The lithology of the CON01-603-2 core, corresponding to the upper part of Unit 1 on Continent Ridge, is highly diverse, ranging from pure diatom-rich layers to pure detrital clayey layers, with transitional biogenic and detrital lithologies. At least five decimeter- to meter-scale diatom-rich intervals occur: i.e. at 0-7, 70-150, 330-540, 590- 
930, 1060-1127.5 cm (Fig. 5). The detrital components represent around 25\% of the cumulated thickness of the sediment core and are dominated by clays to silts. As an exception, two millimetric sandy layers with sparse gravels occur near the base of the core (i.e. at 1094-1095 and 1097.5-1098 cm). The texture of the core is variable: homogeneous (mainly in the clayey intervals), diffuse, finely laminated (especially in the clayey diatom-rich intervals) or in places coarsely laminated (in the pure diatom layers). The core presents many sedimentary structures (plan parallel or lenticular bedding, cross stratification, erosive scouring) and is strongly affected by many tectonic features, especially by faults in the upper $2 \mathrm{~m}$ and between $\sim 680$ and $1020 \mathrm{~cm}$ depth (Fig. 5). Some slumps occur at around 400, 550, 600, 710, 850 and $1060 \mathrm{~cm}$ depth. Diffuse bioturbation and burrows affect biogenic and detrital layers at equal intensity. However, the biggest burrows mostly occur in diatom-rich layers. Small lenses of diatoms and flocs are present in the lowest diatom-rich interval.

\section{Discussion}

\subsection{Main sources of terrigenous supply to the isolated highs}

The sediment cores from two of the three study areas (Continent Ridge and Posolsky Bank) show a hemipelagic lithological succession typical of elevated areas in Lake Baikal, and similar to what has previously been reported from the Academician Ridge area (e.g. BDP-96 members, 1997; Grachev et al., 1998; Antipin et al., 2001; Prokopenko et al., 2001; Fagel et al., 2003). They consist of an alternation of greenish clayey muds and olivecolored biogenic diatom-bearing intervals. This characteristic alternation of predominantly biogenic- and terrigenous-dominated intervals is interpreted as reflecting warm (interglacial/interstadial) and cold (glacial/stadial) periods, respectively.

The relatively strong abundance of the detrital fraction reflects the influence of the fluviatile inputs, and the proximity of the main local tributaries:

- The Vydrino Shoulder core (CON01-605-3) comprises 90\% of detrital material, and represents a nonhemipelagic setting. The side-scan sonar data clearly indicate that sediment transport in the Vydrino Shoulder area occurs mainly via a system of canyons or deeply incised channels. The presence of bedforms in the channel floor suggests active sediment transport under the influence of mass flows, turbidites or hyperpicnal flows. In such a context, the ridges between the channels most likely represent levee environments and the dominant sedimentary process would be overbank deposition out of turbid plumes. The core is characterised by the occurrence of repeated decimetric yellowish sandy-layers (such layers do not occur in the other two coring locations). The internal structure of those coarser layers cannot be detailed (due to the low contrast) on X-ray radiographs. They are in agreement with a turbiditic origin of these deposits. In addition, the homogeneous plurimetric clayey interval at the base of the core, and also visible on the pinger profiles, could represent a major mass-wasting event. The source of the terrigenous supply to Vydrino Shoulder would be either the upper slope of the area (turbidites and mass flows, generated by destabilized upper-slope deposits), or drainage from the Hamar-Daban Mountain Range by the Snezhnaya and Khara Murin Rivers (hyperpicnal flows due to floods).

- The Posolsky Bank core (CON01-604-2) consists for 70\% of detrital material. Posolsky Bank is in the immediate vicinity of the Selenga River delta (less than $35 \mathrm{~km}$ ). The Selenga River is the main tributary of Lake Baikal (actual discharge: $31 \mathrm{~km}^{3} /$ year), and its delta is one of the largest fresh-water river deltas in the World. The sedimentary environment on top of Posolsky Bank is therefore very likely intimately linked to sediment input of the Selenga River, possibly via settling out of interflows or turbid plumes. The thicknesses of the seismic units in the area appear to be strongly related to the water depth. This can also indicate sedimentation out of interflows injected from a local point source.

- In the Continent Ridge core, the detrital component represents $30 \%$ of the thickness. The side-scan sonar mosaic does not show any sediment transport features that would indicate bottom-current influence. The detrital sedimentation seems to be mainly controlled by interflow supplies. The coarser silt fraction and, in particular, the sandy layers at the base of the core nevertheless point to a relatively proximal source: i.e. Barguzin River and/or local rivers along the southeastern coast of the North Baikal Basin. For comparison, the core location is $210 \mathrm{~km}$ from the Selenga River delta, $100 \mathrm{~km}$ from the Barguzin River delta and $25 \mathrm{~km}$ from the coastal rivers.

\subsection{Stratigraphic continuity on the elevated platforms}

The seismic sparker profiles show that the sedimentary cover of each of the elevated platforms is characterised by a succession of several seismic-stratigraphic units, separated by unconformities. These unconformities, which are sometimes erosional in nature (Continent Ridge, Vydrino Shoulder) and sometimes angular (Posolsky Bank), 
provide clear evidence of the presence of discontinuities or hiatuses in the sedimentary record. None of the piston cores, however, penetrated the base of the uppermost seismic-stratigraphic unit in their study area, and therefore they can all be regarded as having sampled a continuous and uninterrupted sedimentary section (i.e. within the limits of the seismic resolution). Comparison of the seismic units with the core descriptions indicates that most of the cores comprise more than one of the climatically conditioned alternations of terrigenous muds and biogenic diatom-bearing intervals. This indicates that climate, at least within the range of glacial-interglacial cycles, is not the cause of the observed unconformities. All observed seismic units represent time intervals that are significantly longer that those of the glacial-interglacial cycles. The observed unconformities are therefore most likely to be attributed to tectonic activity, which is obvious for Posolsky Bank and, to a certain extent, for Continent Ridge, or possibly to tectonically controlled large-scale adjustments in basin dynamics, such as water circulation patterns, currents, etc.

The side-scan sonar records show that the margins of most of the investigated highs are characterised by masswasting features (creeping, slumping, channels, etc.), but that the crests represent areas of undisturbed sediment accumulation. This is particularly evident on Continent Ridge (Fig. 8). The process of sediment remobilisation on the steep slopes of the ridge $\left(\sim 7-8^{\circ}\right)$ is confirmed by a dense grid of short sediment cores, which reveal significant differences in thickness of the Holocene deposits between the crest of the ridge and the flanks.

\subsection{Influence of tectonics on the elevated platforms}

The seismic, side-scan sonar and core data also reveal a distinct overprint of tectonics on all of the study areas:

- The seismic profiles show that the channel-levee systems of Vydrino Shoulder are intersected-to a highly variable degree - by several regional and counter-regional normal faults. Fault activity seems to have decreased through time.

- Posolsky Bank, a major tilted fault-block, is affected by a series of second-order internal faults. Some of the faults extend up to lake floor and affect the recentmost seismic-stratigraphic units (Units 2 to 4), whilst others only influence the older units (Units 3 and 4). Displacements along the fault generally decrease upwards in the section, suggesting a gradual decrease in tectonic activity through time and/or an effect of increased sedimentation rates through time.

- Also Continent Ridge is intersected by a number of large faults. Some of these reach up to the lake floor, whilst others essentially affect the lower seismic-stratigraphic units and appear to splice up into a cluster of microfaults towards younger strata, dying out before reaching the surface (Fig. 9). The tectonic influence on Continent Ridge is also evident in the sediment core, which comprises several unconformities and numerous millimeter- to decimeter-scale faults and slumps. Seismic profiles show the presence of certain intervals with a more or less chaotic seismic facies. These intervals seem to punctuate unconformities and appear to be related to activity along nearby faults. The sparker profile Cont05 (Fig. 9), across the coring site, shows one of such horizons at about 7 mblf. This horizon correlates with a section of core CON01-603-2, which is characterised by the presence of several small faults and slumps in the sedimentary record.

\section{Conclusions}

High-resolution sparker and very-high-resolution pinger data, side-scan sonar mosaics and piston cores from three isolated highs in Lake Baikal (Vydrino Shoulder, Posolsky Bank, Continent Ridge) have allowed us to document, in unprecedented detail, the depositional, re-depositional and tectonic processes and to characterise the overal sedimentary environment on such highs.

New bathymetric data as well as the geophysical site-survey data indicate that Vydrino Shoulder does not really represent an "isolated high". With a distinct channel-levee morphology and up to $90 \%$ of terrigenous material in the core, it forms the main depocentre of a large turbidite system (slope fan). The lacustrine background sedimentation is therefore highly diluted by clastic input, and regularly eroded by turbiditic activity. The system is either sourced by underflows during floods in the adjacent Hamar-Daban Mountain Range (in which case they could hold a valuable and unique record of precipitation in the area), or by turbidites generated by mass-wasting on the upper slope (in which case they could hold a record of seismicity). The channels are conduits for the transfer of coarsegrained sediment towards the deep basin floor, whilst the adjacent levees are formed by overbank deposition out of turbid plumes. Channel walls and levee margins are affected by mass-wasting, and the whole area is affected by faults that show evidence of recent activity. 
Posolsky Bank is a major tilted fault block, cleary affected by tectonic activity and by mass wasting along its margins. The crest of the bank is characterised by relatively undisturbed sedimentation, although a series of distinct angular unconformities indicate the presence of hiatuses. They are probably related to tectonic pulses, the activity of which seems to decrease through time. The bank receives large amounts of clastic input (up to $70 \%$ of the core) from the nearby Selenga River, but-in contrast to Vydrino Shoulder-essentially through hemipelagic settling. This results in little or no erosion of the background sedimentation, but also in relatively high sedimentation rates, particularly in deeper water.

Only $30 \%$ of the total sediment accumulation on Continent Ridge is of terrigenous origin. Some levels with coarser detrital fraction point to an influence of the relatively nearby Barguzin River and/or local rivers along the southeastern coast of the North Baikal Basin. Continent Ridge is also affected by active faulting and by masswasting (creeping, slumping) along its flanks and even on part of its crest. The sedimentary cover is interrupted by some minor unconformities that appear to be associated with fault activity. These unconformities laterally correlate to sediment packages affected by micro-faults in the piston core. There are no signs of sediment reworking due to bottom-currents, as is often observed on the nearby Academician Ridge.

The isolated highs in Lake Baikal (Posolsky Bank and Continent Ridge) are areas of relatively calm and undisturbed sediment accumulation in this large, tectonically active rift lake. Especially the crests of the highs are not affected by turbidite erosion, by sediment reworking, by bottom-currents or by mass-wasting (which is restricted to the slopes of the highs) and they steadily accumulate hemipelagic sedimentation with a variable terrigenous component, depending on their distance from the main tributaries. However, all highs are to a certain extent affected by tectonics. Nevertheless, in comparison with other environments in Lake Baikal, the isolated highs probably hold the best potential to contain a high-quality, continuous, undisturbed and undiluted sedimentary record for paleoclimate research on short, but also long time scales.

This study also illustrates the importance of adequate (i.e. high- to very-high-resolution) site-surveying prior to selecting coring locations.

\section{Acknowledgements}

We thank the captain and crew of R/V Vereshcha-gin and M.A. Grachev (LIN, Irkutsk) for their support, and E. Chapron, T. Pouls and K. De Rycker for their help during the geophysical site survey. We are also grateful to $\mathrm{H}$. Oberhänsli, B. Heim, F. Demory (GFZ, Potsdam), X. Boës (URAP, Liège) and L. Vologina (LIN, Irkutsk) for core sampling and smear slide collection, and to M. Sturm and I. Baster (EAWAG, Switzerland) for constructive discussions and expert advice. We also thank C. Beck and F. Niessen for their helpful comments to the original manuscript. The CONTINENT project was funded by the European Union (FP5) under the Energy, Environment and Sustainable Development Programme (Contract EVK2-2000-00057).

\section{References}

Antipin, V., Afonina, T., Badalov, O., Bezrukova, E., Bukharov, A., Bychinsky, V., Dmitriev, A.A., Dorofeeva, R., Duchkov, A., Esipko, O., Fileva, T., Gelety, V, Golubev, V., Goreglyad, A., Gorokhov, I., Gvozdkov, A., Hase, Y., Ioshida, N, Ivanov, E., Kalashnikova, I., Kalmychkov, G, Karabanov, E., Kashik, S., Kawai, T., Kerber, E., Khakhaev, B., Khlystov, O., Khursevich, G, Khuzin, M., King, J., Konstantinov, K., Kochukov, V., Krainov, M., Kravchinsky, V., Kudryashov, N, Kukhar, L., Kuzmin, M., Nakamura, K., Nomura, Sh., Oksenoid, E., Peck, J., Pevzner, L., Prokopenko, A., Romashov, V., Sakai, H., Sandimirov, 1., Sapozhnikov, A., Seminsky, K., Soshina, N, Tanaka, A., Tkachenko, L., Ushakovskaya, M., Williams, D., 2001. The new BDP-98 600-m drill core from Lake Baikal: a key late Cenozoic sedimentary section in continental Asia. Quat. Int. 80-81, 19-36.

Back, S., De Batist, M., Kirillov, P., Stacker, M.R., Vanhauwaert, P., 1998. The Frolikha fan: a large Pleistocene glaciolacustrine outwashfan in northern Lake Baikal, Siberia. J. Sediment. Res. 68, 841-849.

Back, S., De Batist, M., Stacker, M.R., Vanhauwaert, P., 1999. Quaternary depositional systems in northern Lake Baikal, Siberia. J. Geol. $107,1-12$.

Baikal Drilling Project BDP-96 (Leg II) Members, 1997. Continuous paleoclimate record recovered for last 5 million years. EOS Trans. 78, 597-604.

Battarbee, R.W., 2000. Palaeolimnological approaches to climate change, with special regard to the biological record. Quat. Sci. Rev. 19, 107-124.

Ceramicola, S., Rebesco, M., De Batist, M., Khlystov, O., 2001. Seismic evidence of small-scale lacustrine drifts in Lake Baikal (Russia). Mar. Geophys. Res. 22, 445-464.

Colman, S.M., Peck, J.A., Karabanov, E.B., Carter, S.J., Bradbury, J.P., King, J.W., Williams, D.F., 1995. Continental climate response to orbital forcing from biogenic silica records in Lake Baikal. Nature 378, 769-771. 
Colman, S.M., Karabanov, E.B., Nelson, C.H., 2003. Quaternary sedimentation and subsidence history of Lake Baikal, Siberia, based on seismic stratigraphy and coring. J. Sediment. Res. 73 (6), 941-956.

Fagel, N., Boski, T, Likhoshway, L.V., Oberhänsli, H., 2003. Late Quaternary mineral record in Central Lake Baikal (Academician Ridge, Siberia). Palaeogeogr. Palaeoclimatol. Palaeoecol. 193, 159-179.

Galazy, G.I. (Ed.), Baikal Atlas. Federal Agency for Geodesy and Cartography, Moscow (in Russian).

Goddard, E.N., Trask, P.D., De Ford, R.K., Rove, O.N., Singewald, J.T., Overbeck, R.M., 1948. Rock Color Chart. Geological Society of America.

Grachev, M.A., Vorobyova, S.S., Likhoshway, Y.V., Goldberg, E.L., Ziborova, G.A., Levina, O.V., Khlystov, O.M., 1998. A high-resolution diatom record of the palaeoclimates of East Siberia for the last 2.5 My from Lake Baikal. Quat. Sci. Rev. 17, 1101-1106.

Hutchinson, D.R., Golmshtok, A.J., Zonenshain, L.P., Moore, T.C., Scholz, C.A., Klitgord, K.D., 1992. Depositional and tectonic framework of the rift basins of Lake Baikal from multichannel seismic data. Geology 20, 589-600.

INTAS Project 99-1669 Team, 2002. A New Bathymetric Map of Lake Baikal. CD-ROM.

Kashiwaya, K, Ochiai, S., Sakai, H., Kawai, T, 2003. Onset of current Milankovitch-type climatic oscillations in Lake Baikal sediments at around 4 Ma. Earth Planet. Sci. Lett. 213 (3-4), 185-190

Kögler, F.C., 1963. Das Kastenlot, vol. 13. Meyniana, Kiel, pp. 1 -7.

Kuzmin, M.I., Karabanov, E.B., Prokopenko, A.A., Gelety, V.F., Antipin, V.S., Williams, D.F., Gvozdkov, A.N., 2000. Sedimentation processes and new age constraints on rifting stages in Lake Baikal: results of deep-water drilling. Int. J. Earth Sci. 89, $183-192$.

Mats, V.D., Khlystov, O.M., De Batist, M., Ceramicola, S., Lomonosova, T.K., Klimansky, A., 2000. Evolution of the Academician Ridge accommodation zone in the central part of the Baikal Rift, from high-resolution reflection seismic profiling and geological field investigations. Int. J. Earth Sci. 89, 229-250.

Meischner, D., Rumohr, J., 1974. A light-weight, high momentum gravity corer for subaqueous sediments. Senkenb. Marit. 6 (1), $105-117$.

Nelson, C.H., Karabanov, E.B., Colman, S.M., 1995. Late Quaternary Lake Baikal turbidite systems, Russia. In: Pickering, K.T., Hiscott, R.N., Kenyon, N.H., Ricci Lucci, F, Smith, R.D.A. (Eds.), Atlas of Deep Water Environments: Architectural Style in Turbidite Systems. Chapman and Hall, London, pp. 29-33.

Nelson, C.H., Karabanov, E.B., Colman, S.M., Escutia, C, 1999. Tectonic and sediment supply control of deep rift lake turbidite systems: Lake Baikal, Russia. Geology 27, 163-166.

Nikolayev, V.G, Vaniakin, L.A., Kalinin, V.V., Milanovsky, V.Y, 1985. The sedimentation section beneath Lake Baikal. Int. Geol. Rev. 27, 449-459.

Prokopenko, A.A., Karabanov, E.B., Williams, D.F., Kuzmin, M.I., Shackleton, N.J., Crowhurst, S.J., Peck, J.A., Gvozdkov, A.N., King, J.W., 2001. Biogenic silica record of the Lake Baikal response to climatic forcing during the Brunhes. Quat. Res. 55, 123-132.

Scholz, C.A., Hutchinson, D.R., 2000. Stratigraphic and structural evolution of the Selenga Delta. Accommodation Zone, Lake Baikal Rift, Siberia. Int. J. Earth Sci. 89, 212-228.

Scholz, C.A., Klitgord, K.D., Hutchinson, D.R., ten Brink, U.S., Zonenshain, L.P., Golmshtok, A.Y., Moore, T.C., 1993. Results of 1992 seismic reflection experiment in Lake Baikal. Eos Trans. 74, 465-470.

USSR Ministry of Defence, 1992. Bathymetry charts of Lake Baikal, Siberia. Chief Directirate of Navigation and Ocean-igraphy, Moscow (scale 1:200,000).

Williams, D.F., Peck, J., Karabanov, E.B., Prokopenko, A.A., Kravchinsky, V, King, J., Kuzmin, M.I., 1997. Lake Baikal record of continental climate response to orbital insulation during the past 5 million years. Science 278, 1114-1117.

Williams, D.F., Kuzmin, M.I., Prokopenko, A.A., Karabanov, E.B., Khursevich, G.K., Bezrukova, E.V., 2001. The Lake Baikal drilling project in the context of a global lake drilling initiative. Quat. Int. 80-81, 3-18.

Zonenshain, L.P., Golmshtok, A.Y., Hutchinson, D.R., 1992. Baykal rift structure. Geotectonics 26, 396-407.

Zorin, Y.A., 1971. Recent Structure and Isostasy of the Baikal Rift Zone and Adjacent Territories (in Russian). Nauka, Moscow (168 pp.). 